\title{
PERAN BRAND ATTRACTIVENESS SEBAGAI VARIABEL INTERVENING PADA BRAND DISTINCTIVENESS, BRAND PRESTIGE, BRAND SOSIAL BENEFIT, DAN MEMORABLE BRAND EXPERIENCE TERHADAP CUSTOMER BRAND IDENTIFICATION
}

\author{
Kris Jati Kesuma JP \\ Program Studi Magister Manajemen Universitas Tarumanagara \\ krisjatikesuma@gmail.com \\ Hetty Karunia Tunjung Sari \\ Program Studi Magister Manajemen Universitas Tarumanagara
}

\begin{abstract}
The rapid development in the tourism sector is accompanied by an increase in foreign tourist arrivals, making the Indonesia's hotel industry which is part of the tourism sector, growing dramatically. Competition between brands is unavoidable, each hotel must develop its own brand strategy. This study aims to add insight into brand management specifically in the hotel industry. This study used a quantitative method by distributing questionnaires to 219 respondents who lived in Jabodetabek and had stayed at five-star hotels located in Java and Bali. From this study it can be concluded that the role of brand attractiveness in giving indirect effects to brand prestige, brand distinctiveness, brand social benefits, and memorable brand experience on customer brand identification. This study also stated the importance of brand prestige, brand distinctiveness, and brand social benefits significantly and positively influences customer brand identification directly.
\end{abstract}

Abstrak : Perkembangan pada sektor wisata yang disertai dengan bertambahnya kedatangan wisatawan asing, menjadikan industri perhotelan indonesia yang merupakan bagian dari sektor wisata semakin berkembang dengan cepat.Persaingan antar merek sudah tidak dapat dihindari, setiap hotel harus mengembangkan strategi mereknya. Penelitian ini menggunakan metode kuantitatif denganmembagikan kuesioner kepada 219 responden yang tinggal di Jabodetabek dan pernah menginap pada hotel berbintang lima yang berlokasi di Jawa dan Bali. Dari penelitian ini dapat disimpulkan bagaimana peran brand attractiveness dalam memberikan efek tidak langsung pada brand prestige, brand Distinctiveness, brand social benefit, dan memorable brand experience terhadap customer brand identification. Penelitian ini juga menyatakan pentingnya brand prestige, brand distinctiveness, dan brand social benefit yang signifikan dan positif memengaruhi customer brand identification secara langsung.

Keywords : Brand Attractiveness, Brand prestige, Brand Distinctiveness, Brand Social Benefits, Memorable Brand Experience, Customer Brand Identification.

\section{PENDAHULUAN}

Indonesia memiliki tempat-tempat menarik untuk menjadi destinasi wisata yang indah, reruntuhan budaya dan peninggalan sejarah yang menarik, pantai-pantai, kehidupan malam dan banyak lagi. Menjadikan Indonesia menarik jutaan turis asing untuk berkunjung dan menghabiskan waktu berwisata. Indonesia telah berhasil menyambut hampir 10 juta turis asing pada tahun 2015, dan angka ini masih terus bertumbuh dari tahun ketahunnya. Besar peranan sektor pariwisata Indonesia dalam meningkatkan produk domestik bruto (PDB) dengan banyak menghasilkan pendapatan devisa. Ketua umum persatuan hotel dan restoran indonesia (PHRI), Haryadi Sukamdani menjelaskan bahwa sektor pariwisata Indonesia yang sangat menjanjikan dan sektor ini adalah core business Indonesia. Pariwisata menjadi penyumbang PDB, devisa, serta lapangan kerja paling besar dan mudah dan cepat (Cahyu, 24 September, 2018). 
So et al (2013) menjelaskan dalam industri hotel yang sangat kompetitif, di mana produk dan layanan telah mencapai status "komoditas". Dalam bisnis perhotelan diharuskan menemukan cara untuk bagaimana membedakan produk dan layanan mereka dari yang lain (Choi \& Chu, 2001). Kebutuhan ini memunculkan ide penggunaan strategi branding sebagai sumber diferensiasi dan keunggulan kompetitif, menjadikan merek (Brand) sebagai salah cara yang paling efektif dalam industri perhotelan global (Kayaman \& Arasli, 2007). Membangun merek (brand) hotel yang kuat adalah dengan menciptakan integrasi nilai bagi perusahaan dan pelanggan.

So et al (2013) menuliskan identifikasi konsumen dengan merek (customer brand identification), berasal dari teori identitas sosial, dapat mempengaruhi ke berbagai hasil termasuk loyalitas merek (brand loyalty). Kuenzel \& Halliday (2008) juga percaya bahwa konsep identifikasi konsumen dengan merek (customer brand identification) memberikan pemahaman yang lebih kaya tentang manajemen merek dan mengusulkan bahwa identifikasi konsumen dengan merek (customer brand identification) yang kuat dapat mendorong evaluasi merek yang disukai pelanggan. So et al (2017) menyatakan bahwa konsep identifikasi konsumen dengan merek (customer brand identification) memberikan pemahaman yang mendalam tentang bagaimana hubungan merek pelanggan berkembang. Dalam penelitian perhotelan, penelitian terbaru menunjukkan bahwa identifikasi konsumen dengan merek (customer brand identification) menghasilkan evaluasi konsumen yang positif, dan kepuasan terhadap merek hotel, yang pada akhirnya meningkatkan loyalitas merek (Nam, Ekinci \& Whyatt, 2011; Jadi, King., Sparks, \& Wang, 2013).

Literatur pemasaran menunjukkan bahwa sejauh mana konsumen mengidentifikasi suatu merek secara langsung akan dipengaruhi oleh dua faktor. Faktor pertama meliputi karakteristik merek yang tercermin dalam identitas merek, prestise merek (brand prestige) yang paling dominandan keunikan merek (brand distinctiveness) (So et al, 2017). Faktor lainnya melibatkan faktor-faktor yang menonjol terutama melalui interaksi merek dengan pelanggan termasuk yang menjelaskan adalah manfaat sosial merek (brand social benefits) dan pengalaman yang mengesankan dengan merek (bemorable brand experience), yang mewakili pengalaman yang dimiliki pelanggan dengan merek layanan. Meskipun faktor ini menerima perhatian yang relatif sedikit dalam konteks identifikasi konsumen dengan merek (customer brand identification), mereka sangat penting dalam memahami bagaimana konsumen mengindetifikasi suatu merek layanan di mana transaksi secara fundamental ditandai oleh interaksi manusia (So et al, 2017).

Strategi branding dalam industri perhotelan, membutuhkan pemahaman yang lebih besar tentang peran yang dimainkan identifikasi konsumen dengan merek (customer brand identification) dalam menciptakan hubungan pelanggan-merek yang kuat. Wawasan ini sangat penting, karena identifikasi konsumen dengan merek (customer brand identification) mewakili keterikatan psikologis yang kuat dengan merek, yang berpotensi bertahan lama dan menunjukkan perilaku masa depan. Penelitian sebelumnya menjelaskan bagaimana peran daya tarik merek (brand attractiveness) dalam membangun identifikasi konsumen dengan merek (customer brand identification) pada industri penerbangan. Dimana daya tarik merek (brand attractiveness) adalah evaluasi positif konsumen terhadap identitas merek sehubungan dengan bagaimana hal itu membantu konsumen memenuhi kebutuhan mereka sendiri, maka dapat disimpulkan daya tarik merek merupakan aspek mendasar dari proses identifikasi (So et al, 2017). Tetapi peran daya tarik merek (brand attractiveness) dalam membangun identifikasi konsumen dengan merek (customer brand identification) belum dapat dijelaskan pada industri perhotelan. Penelitian ini secara empiris meneliti peran daya tarik merek dalam membangun identifikasi konsumen dengan merek perhotelan dan atas dasar ulasan tersebut, kami mengusulkan model konseptual untuk memandu penelitian ini (Gambar 1). 
K.K.F. So et al. / Tourism Management 59 (2017) 640-65

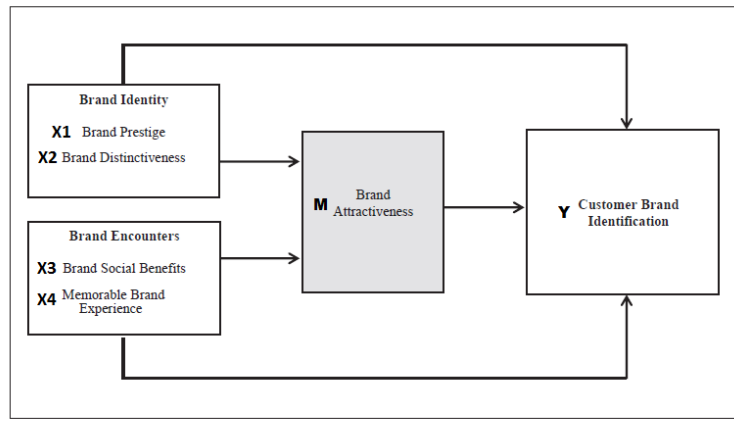

Gambar 1. Kerangka pemikiran

\section{CUSTOMER BRAND INDENTIFICATION}

Identifikasi konsumen dengan merek (customer brand identification) diartikan seperti apa yang dirasakan konsumen menjadi satu dengan merek. Pengertian ini sama dengan penelitian perilaku organisasi yang menyimpulkan bahwa identifikasi biasanya diartikan persepsi kesatuan atau rasa memiliki antara manusia (Fathoni \& Astuti, 2015). Identifikasi konsumen dengan merek atau customer brand identification merupakan pandangan individu terhadap suatu merek yang akan mempengaruhi konsumen dengan merek tersebut. Pengalaman kita dengan merek sama seperti kita berbicara dengan orang lain, alasan tersebut yang membuat seseorang mengindentifikasi merek (Fathoni \& Astuti, 2015). Escalas (2003) menjelaskan bahwa identifikasi konsumen dengan merek (customer brand identification) merupakan motivasi dari seorang individu untuk dapat menjalin hubungan dengan merek.

Sektor pariwisata lebih khusus lagi industri perhotelan telah secara luas mengadopsi strategi branding untuk menetapkan produk dan jasa terpisah dari pesaing, menekankan relevansi khusus customer brand identification dalam memeriksa hubungan merek dengan kosumen (Fathoni \& Astuti, 2015). Namun, para pakar pariwisata menggambarkan customer brand identification sebagai konstruksi penting namun kurang dimanfaatkan, mewakili keterikatan psikologis yang kuat yang berpotensi bertahan dan menunjukkan perilaku masa depan (So et al, 2013). Dari sudut pandang psikologis Lam et al (2013) menjelaskan customer brand identification merupakan pernyataan dari dalam diri konsumen untuk mempersepsikan, merasakan dan menilai suatu kepemilikan dengan merek.

\section{BRAND ATTRACTIVENESS}

Daya tarik merek (brand attractiveness) berdasarkan pada evaluasi positif konsumen dengan merek tersebut. Daya tarik merek (brand attractiveness), akan mendorong konsumen untuk mencari informasi tentang merek tersebut. Penelitian sebelumnya menjelaskan bahwa anteseden umum, seperti prestise merek (brand prestige), mempengaruhi customer brand identification secara langsung. Namun, konsumen akan mengidentifikasi secara berbeda terkait prestise itu, seperti dapat dirasakan secara berbeda di seluruh kelompok konsumen. Ini karena identifikasi lebih mungkin terjadi ketika kosumen menemukan perusahaan atau merek menjadi menarik, dan identitas merek (brand identity) yang menarik dapat meningkatkan evaluasi diri konsumen (So et al, 2017). Dengan demikian, seorang konsumen yang menganggap identitas suatu merek sebagai menarik lebih mungkin untuk mengidentifikasi dengan merek dan menggabungkan identitas itu.

\section{BRAND PRESTIGE}

Prestise merek (brand prestige) berarti persepsi emosional atau logis dari kosumen mengenai merek tertentu terutama ketika sulit untuk membedakan produk berdasarkan karakteristik kualitatif yang nyata, prestise memainkan peran penting dalam perilaku belanja 
kosumen. Oleh karena itu identitas nilai merek dianggap sebagai aset penting, dan merek yang kuat meningkatkan kepercayaan kosumen dalam membeli produk dan layanan. Bahkan memungkinkan mereka untuk memahami dan membayangkan nilai-nilai tak berwujud dengan baik. Faktor penting daya tarik merek (brand attractiveness) adalah prestise merek (Brand prestige), yang merupakan status atau harga yang terkait dengan merek (So et al, 2017). Individu cenderung mempertahankan identitas sosial yang positif dengan berafiliasi dengan perusahaan atau merek bergengsi karena afiliasi tersebut memberikan peluang untuk meningkatakan status dan prestise sosial. Identifikasi merek yang memiliki identitas bergengsi memungkinkan kosumen untuk melihat diri mereka dalam sebuah kejayaan, meningkatkan rasa harga diri dan status sosial mereka.

\section{BRAND DISTINCTIVENESS}

Wong \& Merrilees (2008) menjelaskan bahwa keunikan merek (brand distinctiveness) adalah seni menjadi unik dan diinginkan oleh target kosumen, bahwa perusahaan berusaha untuk menciptakan beberapa bentuk keunikan merek (brand distinctiveness) untuk menghindari produk mereka dipandang sebagai barang yang pasaran atau mudah didapatkan. Keunikan merek (brand distinctiveness) juga menghasilkan keunggulan kompetitif bagi perusahaan, kosumen tidak memiliki dasar untuk memilih merek tertentu daripada merek lain jika suatu merek tidak dianggap berbeda (Aaker, 1996). Keunikan suatu merek dapat menjadi pendahulu utama keinginan kosumen untuk mengidentifikasi merek tersebut (StokburgerSauer et al, 2012). Oleh karena itu, kosumen lebih cenderung untuk mengidentifikasi merek dengan identitas yang berbeda dari pesaing mereka jika keunikan tidak dianggap sebagai tidak diinginkan atau negatif.

\section{BRAND SOCIAL BENEFIT}

Nelissen \& Meijers (2010) dalam penelitiannya menyatakan bahwa merek terutama merek mewah memang menghasilkan peningkatan persepsi status dan memunculkan perlakuan istimewa dalam interaksi sosial. Setiap orang yang memiliki hubungan dengan merek yang digunakannya terutama atas pandangan orang lain terhadap status sosialnya. Dengan kata lain merek memberikan manfaat sosial terutama atas persepsi seseorang atas status sosialnya. So et al (2017) menuliskan manfaat sosial merek (brand social benefits), diartikan sebagai peluang interaksi sosial dan keuntungan yang diberikan oleh suatu merek, merupakan faktor penting dalam pengembangan identifikasi konsumen dengan merek (customer brand identification).

\section{MEMORABLE BRAND EXPERIENCE}

Menurut Brakus et al (2009) brand experience didefinisikan sebagai sensasi, perasaan, kognisi dan tanggapan konsumen yang ditimbulkan oleh merek, terkait rangsangan yang ditimbulkan oleh desain merek, identitas merek (brand identity), komunikasi pemasaran, orang dan lingkungan merek tersebut dipasarkan. Dalam konteks pariwisata, pengalaman yang mengesankan dengan merek (memorable brand experience) adalah kontributor yang sangat penting bagi Identifikasi konsumen dengan merek (customer brand identification) mengingat peran sentral yang dimainkan oleh service encounters dalam evaluasi kosumen terhadap merek (So et al, 2017). So et al (2017) menuliskan bahwa beberapa penelitian empiris mendukung pentingnya menciptakan pengalaman wisata atau pengalaman yang berkesan.Merek yang menawarkan pengalaman yang mengesankan (memorable brand experience) lebih cenderung mengarah pada jalinan individu terkait pemikiran merek dan yang berkaitan dengan diri sendiri, sehingga berkontribusi terhadap identifikasi konsumen dengan merek atau customer brand identification (Stokburger-Sauer et al, 2012). 


\section{METODELOGI PENELITIAN}

Dalam menguji hipotesis, penulis mengadopsi metode kuantitatif yang terdiri dari kuesioner survei online yang mengukur persepsi pelanggan terhadap merek hotel pilihannya. Kuesioner penelitian dengan skala likert 7 skala (sangat tidak setuju - sangat setuju) yang disebarkan kepada 241 responden dengan kriteria yang telah ditentukan (purposive sampling). Adapun varibel yang digunakan pada penelitian ini adalah brand prestige, brand distinctiveness, brand social benefits, memorable brand experience sebagai variabel independen, customer brand identification sebagai variabel dependen, dan brand attractiveness sebagai variabel mediasi. Penelitian ini menggunakan Uji Hayes dengan menggunakan program SPSS 21 untuk menjelaskan hubungan antara varibel serta menggambarkan pengaruh antara varibel.

\section{HASIL \& KESIMPULAN}

Hasil penelitian ini (Gambar 2) menunjukan bahwa brand attractiveness berperan dalam membangun customer brand identification, yang dapat dijelaskan bagaimana brand attractiveness mediasi efek tidak langsung dari brand prestige, brand distinctiveness, brand social benefits, dan memorable brand experience terhadap customer brand identification. Selain itu hasil penelitian juga menunjukan bagaimana brand prestige, brand distinctiveness, brand social benefits memberikan efek langsung terhadap customer brand identification.

\begin{tabular}{|c|c|c|c|c|}
\hline \multicolumn{5}{|c|}{$\begin{array}{c}\text { Hasil Uji Direct Effect (Hayes, 2013) } \\
\text { Terhadap Variabel Y (Customer Brand Identification) }\end{array}$} \\
\hline Var & Effect Size & $L L C I$ & ULCI & Hubungan \\
\hline Brand Prestige &, 928 & 600 & 1,255 & Valid \\
\hline Brand Distinctiveness & .883 & .827 & 1,516 & Valid \\
\hline Brand Social Benefit &, 747 & .578 & 916 & Valid \\
\hline Memorable Brand Experience & .303 & -.044 & .649 & Tidak Valid \\
\hline \multicolumn{5}{|c|}{$\begin{array}{c}\text { Hasil Uji Indirect Effect (Hayes, 2013) } \\
\text { melalui mediasi Variabel M (Brand Attractiveness) } \\
\text { terhadap Variabel Y (Customer Brand Identification) }\end{array}$} \\
\hline Var & Effect Size & $L L C I$ & ULCI & Hubungan \\
\hline Brand Prestige &, 318 & .162 & .504 & Valid \\
\hline Brand Distinctiveness & .288 & .096 & 472 & Valid \\
\hline Brand Social Benefit & .172 & .091 & .916 & Valid \\
\hline Memorable Brand Experience & .619 & .421 & .830 & Valid \\
\hline
\end{tabular}

\section{Gambar 2. Hasil Efek Langsung dan Tidak Langsung}

Pada penelitian ini dapat disimpulkan bahwa daya tarik merek Brand Attractiveness secara signifikan berpengaruh positif terhadap identifikasi konsumen dengan merek (customer brand identification) bagi para konsumen hotel bintang lima. Dimana daya tarik merek (brand attractiveness) akan mendorong konsumen untuk mencari informasi tentang merek (So et al, 2016) yang secara tidak langsung membantu konsumen dalam mengindentifikasi merek tersebut dengan identitas pribadi. Dengan demikian, seorang konsumen yang menganggap identitas suatu merek yang menarik lebih mungkin untuk mengidentifikasi dirinya dengan merek. Ketika seorang konsumen melihat citra merek yang ditafsirkan dari suatu perusahaan sebagai menarik, hal tersebut akan menjadi atribut yang membedakan perusahaan secara positif dan dihargai secara sosial oleh orang lain dengan relevan, maka identifikasi dengan perusahaan itu diperkuat (Ahearne et al., 2005).

\begin{tabular}{|c|c|c|c|c|}
\hline \multicolumn{5}{|c|}{$\begin{array}{l}\text { Hasil Hubungan Langsung Variabel X Terhadap Variabel Y } \\
\text { (Customer Brand Identification) }\end{array}$} \\
\hline Var_X & $\mathrm{t}$ & $\mathrm{R}$ & R-Square & $\mathrm{P}$ \\
\hline BrandPrestige & 6,947 & , 427 &, 183 &, 000 \\
\hline Brand Distinctiveness & 6,704 &, 415 &, 172 &, 000 \\
\hline Brand Social Benefit & 12,286 &, 621 & ,411 &, 000 \\
\hline Memorable Brand Experience & 6,360 &, 397 &, 158 &, 000 \\
\hline \multicolumn{5}{|c|}{$t$ Tabel $: 1,971$} \\
\hline
\end{tabular}

Gambar 3. Hasil Hubungan Langsung Variabel X terhadap Variabel Y 


\section{Daftar Pustaka}

Ahearne, M., Bhattacharya, C. B., \& Gruen, T. (2005). Antecedents and consequences of customer company identification: Expanding the role of relationship marketing. Journal of Applied Psychology, 90, 574 - 585.

Choi, T.Y., \& Chu, R. (2001). Determinants of hotel guests' satisfaction and repeat patronage in the Hong Kong hotel industry. International Journal of Hospitality Management, 20, 277-297.

Fathoni, Mutiaul, \& Astuti, R.D. (2015). Pengaruh Consumer Brand Identity Terhadap Brand Loyalty dan Brand Advocacy Pada Produk Smartphone Samsung. Journal of Universitas Indonesia.

Fitriyani, A., \& Mardhiyah, D. (2017). Analisis Pengaruh Program Cause-related Marketing terhadap Citra Perusahaan, Brand Attractiveness dan Keputusan Pembelian Konsumen. Prosiding Simposium II - UNIID 2017, 153 - 158.

Kayaman, R., \& Arasli, H. (2007). Customer based brand equity: evidence from the hotel industry. Journal of Managing Service Quality, 17, 92-109.

Lam, S. K., Ahearne, M., Mullins, R., Hayati, B., \& Schillewaert, N. (2013). Exploring the dynamics of antecedents to consumerebrand identification with a new brand. Journal of the Academy of Marketing Science, 41, 234 - 252.

So, K. K. F., King, C., Hudson, S., \& Mang, F. (2017). The missing link in building customer brand identification: The role ofbrand attractiveness. Journal of Tourism Management, $59,640-651$.

So, K. K. F., King, C., Sparks, B. A., \& Wang, Y. (2013). The influence of customer brand identification on hotel brand evaluation and loyalty development.International Journal of Hospitality Management.

So, K. K. F., King, C., Sparks, B. A., \& Wang, Y. (2016). The role of customerengagement in building consumer loyalty to tourism brands.Journal of Travel Research, 55, 64 - 78.

Stokburger-Sauer, N., Ratneshwar, S., \& Sen, S. (2012). Drivers of consumer-brand identification. International Journal of Research in Marketing, 29, 406 - 418.

Upamannyu, N.K., Bhakar, S.S., \& Chauhan, A.S. (2015). The Effect of Brand Prestige on Brand Preference and Word of Mouth: The Moderator Role of Customer Involvement. Asian Journal of Research in Marketing, 4, 123 - 140. 